\title{
COMPARISON OF FUNDAMENTAL PERIODS OF REINFORCED SHEAR WALL DOMINANT BUILDING MODELS WITH EMPIRICAL EXPRESSIONS
}

\author{
Marijana Hadzima-Nyarko, Dragan Morić, Hrvoje Draganić, Tihomir Štefić
}

Original scientific paper Empirical formulas for the estimation of the fundamental periods have been included in seismic codes, which mainly depend on building height, material (steel, reinforced concrete (RC)) and structural system type (frame, shear wall, etc.). These formulas have been usually derived from empirical data through regression analysis of the measured fundamental period of existing buildings subjected to seismic actions. A parametric study on 480 different RC building models with shear walls was performed with varied parameters: building height, number of bays and the ratio of shear walls area to floor area. The aim of this paper is to verify these empirical expressions, which are given by different authors and seismic codes and to conclude whether the expressions are good enough as a starting assumption for the design of earthquake resistant buildings.

Keywords: EN1998-1; fundamental period; parametric study; RC shear walls; structure models

Usporedba osnovnih perioda modela zgrada s armiranobetonskim zidovima s empirijskim izrazima

Izvorni znanstveni članka

Empirijski izrazi za procjenu osnovnih perioda su sastavni dio propisa za proračun seizmičkih djelovanja te uglavnom ovise o visini, materijalu (čelik, armirani beton) i nosivom sustavu(okvir, posmični zidovi, itd.) građevine. Ovi izrazi su obično nastali iz empirijskih podataka kroz analizu mjerenih osnovnih perioda postojećih građevina pod djelovanjem potresa. Provedena je parametarska studija na 480 modela armiranobetonskih zgrada s posmičnim zidovima s različitim ulaznim podacima: visina zgrade, broj raspona i omjer površine posmičnih zidova i tlocrtne površine zgrade. Cilj ovog istraživanja je provjeriti empirijske izraze različitih autora i seizmičkih propisa u svrhu provjere točnosti izraza kao početnih pretpostavki kod projektiranja potresno otpornih građevina.

Ključne riječi: EN1998-1; armiranobetonski posmični zidovi; modeli zgrada; osnovni period; parametarska studija

\section{Introduction}

The reliable evaluation of the fundamental period constitutes an essential step in the estimation of seismic response in seismic design and assessment. The fundamental vibration period of a building appears in formulas specified in building codes to calculate the design base shear and lateral forces. As the characteristics of the structures that have yet to be designed cannot be known, building design codes provide empirical formulas for fundamental period depending on the building type (frame, shear wall (SW), etc.), material (steel, reinforced concrete (RC)) and global dimensions. The period value is mainly dependent on mass, stiffness, strength and consequently on dimensions in height and plan, morphology, irregularities, members, characteristics, nonstructural elements, stiffness, cracking.

Shear walls are commonly implemented into multistorey buildings because of their good performance under lateral loads like earthquake forces since they provide lateral stability and they act as vertical cantilevers in resisting the horizontal forces. RC structures with shear walls are a less flexible version of moment resisting frame (MRF) structures since the whole concept of the structure is set differently. By an attentive selection of wall stiffness, the horizontal displacement of the building may be regulated. The mass of these buildings is greater than the mass of RC MRF structures and the period of oscillation is shorter than the period of $\mathrm{RC} M R F$ structure. As they are stiffer the period is shorter. This means that they develop, in general, larger seismic forces, but their capacity is much higher, so the developed seismic forces can generally be accepted without much difficulty. In addition, these buildings are much less sensitive to the effects of second order.
When walls and/or core walls are situated in advantageous positions in the building, they can be very efficient in resisting lateral loads originating from wind or earthquakes.

According to Hong and Hwang [1], there are two ways to determine the fundamental vibration period of a structure: theoretical and practical. The theoretical approach needs a simplified model in constituting the mass and stiffness matrices and also in evaluating the elements of these matrices. Practical approach uses measurements in the real structure to identify its fundamental vibration period.

The most valuable data base of periods is from structures shaken strongly but not deformed into the inelastic range, however, this is often difficult to achieve. Such data are slow to accumulate because relatively few structures have permanently installed accelerometers and earthquakes causing strong motions of these instrumented buildings are infrequent [2].

The fundamental period of vibration calculated by currently available approximate equations show remarkable differences between "code-estimated" and "measured" period values for actual structures $[3 \div 6]$. In the case of apartment buildings with the shear-wall dominant systems, it has long been realized that comparatively large errors are likely to occur when this formula is used, because it gives a much shorter period in the longitudinal direction and longer in the transverse direction than periods obtained from dynamic analysis [7].

Therefore, a parametric study on a RC structure models with shear walls was performed with varied parameters: building height, number of bays and ratio of shear wall area to floor area with the aim to compare empirical expressions, which are given by different 
authors and seismic codes. The aim of the paper is to investigate and to reach a conclusion whether the expressions in seismic codes are good enough as a starting assumption for the design of earthquake resistant buildings.

\section{Previous research}

Essentially, according to Oliveira [8], there are two ways to obtain the dynamic characteristics of a building: 1) by experimental monitorization of areal building for different input motion; 2) by numerical modelling based on the mechanical properties of building components. Both are important and complementary, the second being a way to calibrate the first.

\subsection{Dynamic characteristic of reinforced building by experimental monitorization}

Housner and Brady [9] published a theoretical analysis for an idealised building with shear walls with expressions derived from the Rayleigh method. They compared results with the expressions given by Californian Building Code of 1960 and measured periods on 77 steel and RC buildings during the 1993 Long Beach earthquake in California. The conclusion was that the use of realistic stiffness/bearing of shear walls would provide better code assessment of seismic characteristics of buildings.

Cole et al. [10] compared expressions for periods given in UBC-91 with the data recorded on 64 buildings during some Californian earthquakes. They concluded that measured periods of frame structures are in general longer than those calculated by expressions and that the difference is about 1.4 times. For buildings with shear walls it was concluded that the measured period is much shorter than that calculated by the expressions.

$\mathrm{Li}$ and Mau [11] analysed measurements from 21 buildings during the Loma Prieta and Whittier earthquake. The measured fundamental periods were compared with the expressions from UBC-94 code. They noticed that the fundamental period of RC frames are underestimated, while the period of SW buildings were overestimated in some cases and underestimated in other cases. They also concluded that values given by other building codes for SW buildings depend only on the length and height of walls of the first floor and that the results are similar to prior codes.

Goel and Chopra [2] compared fundamental periods of SW buildings on 16 buildings measured during several Californian earthquakes with the values given by codes. They discovered that the expressions in codes result in a longer fundamental period than the measured one which produces non-conservative shear forces. When they used different values of $C_{\mathrm{t}}$ (Eq. (1)) derived from combined effective area, the result was a much shorter period than the measured one. They also concluded that the expression from ATC3-06 [12] which uses building dimension at the base for the investigated direction significantly underestimates the period. Goel and Chopra also proposed new expressions based on Dunkerley's method and the restriction of the period to 1.4 times the value from the rational analysis.
Lee et al. [7] measured fundamental periods on 50 RC apartment buildings with shear walls, and these results were compared with those obtained by code formulas and also by dynamic analysis. The comparison showed that comparatively large errors are likely to occur when code formulas were used. Lee et al. concluded that none of the code formulas examined in their study are sufficient for estimating the fundamental period of apartment buildings with SW dominant systems.

Jalali and Salem [13] conducted ambient vibration measurements on $30 \mathrm{RC}$ buildings in Tehran and Tabriz designed according to Iranian code and compared the results of such measurements with code formulas. The results showed that in all cases the fundamental periods predicted from ambient vibration measurements fall below those obtained from empirical formulas of the code.

Galipoli et al. [14] performed ambient noise measurements on $244 \mathrm{RC}$ buildings from 1 to 20 floors in four European countries. They found that the most striking feature is the similarity of the height-period relationships in the four countries. They calculated a regression that is very similar to other empirical heightperiod relationships and quite different from code provisions and theoretical models.

Kwon and Kim [3] evaluated building period formulas in seismic design code with over 800 apparent building periods from 191 building stations and 67 earthquake events. The evaluation was carried out with the formulas in ASCE 7-05 for steel and RC MRF, SW buildings, braced frames and other structural types. The differences between the periods from code formula and measured periods of low- to-medium rise buildings were relatively high. The code formula for SW buildings overestimated periods for all building heights.

\subsection{Dynamic characteristic of reinforced building using numerical modelling}

Hart et al. [15] investigated the 10-storey RC building under Whittier earthquake in California. The fundamental period was calculated with ETABS computer software in three phases of collapse: full sections phase, appearing of the cracks on beams and failure of both beams and columns. The best compliance with the measured results was achieved with the phase of failure of both beams and columns.

Ventura and Schuster [16] investigated a 30-storey RC SW building in Vancouver. They monitored ambient vibrations during different phases of construction and after all architectural elements were installed. The results showed a small influence of non-constructive elements on the buildings behaviour. The calculation was conducted according to UBC-97 and NBCC and the conclusion was that experimental and analytical derived frequencies coincided very well.

Naeim [17] investigated dynamical characteristics and seismic response from the records during the Northridge earthquake on 17 buildings in Los Angeles area. The buildings were of different structural systems and the investigation collected information on the state and degree of damage on buildings and some details 
during the earthquake. The research also investigated the assessment of the building response.

Anderson and Bertero [18] analysed the seismic behaviour of the San Bruno Office Building. The fundamental periods from earthquake measurements were somewhat bigger than the ones from the ambient vibration. Better results for the periods were achieved by introducing $50 \%$ weakening of the columns.

De la Llera and Chopra [19] compared measured and analytically calculated dynamical behaviour of 8 buildings with different structural systems under the influence of Northbridge earthquake 1994. They assumed the floors to be rigid and concentrated the mass in their position/height. The assessment was conducted on three types of buildings: "The Van Nuys Hotel" which exhibited shorter fundamental periods for analytical calculation; "Los Angeles Warehouse Building" with peripheral ductile RC frames which showed less difference and the third building "The Burbank Building", consisted of prefabricated RC walls in two directions, showed the smallest differences between measured and calculated periods.

Balkaya and Kalkan [20] investigated Consistency of equations in seismic codes (Uniform Building Code, International Conference of Building Officials, [21]) and the Turkish Seismic Code ([22]) related to their dynamic properties. They observed that the given empirical equations for prediction of fundamental periods of SW dominant multi-storey RC structures yield inaccurate results. Therefore, they performed an analytical study on 80 different building configurations by using threedimensional finite-element modelling and proposed a set of new empirical equations.

Verderame et al. [23] studied existing RC MRF buildings designed in the 1950-ties and tried to capture the dependency of the elastic dynamic properties as a function of mass and stiffness. They divided the buildings into two groups: gravity load designed and seismically designed. Studied buildings showed significantly larger periods when using EN1998-1 and authors proposed introduction of a global parameter (e.g. plan area) for faster period evaluation.

Draganić et al. [5] performed an analytical investigation of 600 different models of RC framed structures with varied column dimensions in order to verify empirical expressions, which are given by different authors and EN1998-1. Using the same database of modelled RC MRF structures, Hadzima-Nyarko et al. [24] proposed new expressions for fundamental periods of regular $\mathrm{RC}$ frames which take into account the direction of the structure considered, by performing nonlinear regression analysis using genetic algorithm.

Ricci et al. [25] conducted a 3D modelling analysis of infilled RC MRF structures with varying structural morphology and infill characteristics. They concluded that the area of infill walls through the ratio between the infill area and the total building area influences the fundamental period.

Since previous analytical research was mainly conducted on RC MRF buildings, in this study investigation of analytically obtained periods on RC SW dominant structures will be performed, which will be compared with the expressions given in seismic codes, with the emphasis on expressions given in EN1998-1 [26].

\section{Empirical formulae given by building codes}

Approximate expressions may be used for the preliminary design in order to calculate the fundamental period of vibration $\mathrm{T}$ of the structure. These expressions given in design codes are presented further in the text.

\subsection{Empirical formulae according to Eurocode 8 [26]}

According to the European code EN1998-1 [26], for the structures with height up to $40 \mathrm{~m}$, the fundamental period can be approximate with the expression:

$T=C_{\mathrm{t}} \cdot H^{0,75}$,

where $T$ is fundamental period of vibration of the structure (s) and $H$ is height of the structure (m).

This form of the expression is obtained with theoretical derivation using Rayleigh's method with the following assumptions [27]:

a) Equivalent static lateral forces are distributed linearly over the height of the structure;

b) Distribution of the stiffness along the height is made in the way that the interstory drift of the structure with linearly distributed horizontal forces is equal on every storey;

c) Base shear is proportional to $1 / T^{2 / 3}$;

d) Strains are controlled by the serviceability limit states.

Numerical value of the $C_{\mathrm{t}}$ is obtained from measured periods of vibration from the structures after the earthquake in San Fernando in 1971.

For the structures with reinforced concrete or masonry bearing walls the value of $C_{\mathrm{t}}$ may be calculated using:

$C_{\mathrm{t}}=\frac{0,75}{\sqrt{A_{\mathrm{c}}}}$,

and then Eq. (1) becomes:

$T=\frac{0,075}{\sqrt{A_{\mathrm{c}}}} \cdot H^{0,75}$,

with

$A_{\mathrm{c}}=\sum\left[A_{i}\left(0,2+\frac{l_{\mathrm{w} i}}{H}\right)^{2}\right]$

where $A_{\mathrm{c}}$ is the total effective area of shear walls in the first storey of the building $\left(\mathrm{m}^{2}\right), A_{i}$ is the effective crosssectional area of shear wall $i$ in the considered direction on the first storey of the building $\left(\mathrm{m}^{2}\right), l_{\mathrm{w} i}$ is length of the shear wall $i$ on the first storey in the direction parallel to the applied load (m), with the restriction $l_{\mathrm{w} i} / H \leq 0,9$. 


\subsection{Empirical formulae according to ATC3-06 [12]}

ATC3-06 [12] and earlier versions of other U.S. codes specify a different formula (Goel and Chopra, 1998 $[2])$ :

$T=\frac{0,05 H}{\sqrt{D}}$

where $D$ is the dimension of the building at its base in the direction under consideration $(\mathrm{ft})$.

\subsection{Empirical expression obtained by researchers - Goel and Chopra (1998) [2]}

Goel and Chopra [2] collected data on the fundamental vibration period of buildings measured from their motions recorded during several California earthquakes against which code formulas in present U.S. codes are evaluated.

The fundamental period of a cantilever, which takes into account flexural and shear deformations, and uses an equivalent shear area $A_{\mathrm{e}}$, results with the expression on which regression analysis is applied:

$$
T=\bar{C} \frac{1}{\sqrt{\bar{A}_{\mathrm{e}}}} H,
$$

where $\overline{\mathrm{C}}$ is a numerical constant:

$$
\bar{C}=40 \sqrt{\frac{\rho}{\kappa G}},
$$

in which $\rho=m / A_{\mathrm{B}}$ is the average mass density, defined as the total building mass $(=m \cdot H)$ divided by the total building volume $\left(=A_{\mathrm{B}} \cdot H\right) ; A_{\mathrm{B}}$ is the building plan area, $m$ is mass per unit height, $G$ is shear modulus, $\kappa$ is a factor accounting for the shape of the transverse section (equal to $5 / 6$ for a rectangular section), $\bar{A}_{\mathrm{e}}$ is the equivalent shear area expressed as a percentage of $A_{\mathrm{B}}$, i.e.:

$$
\overline{A_{\mathrm{e}}}=100 \frac{A_{\mathrm{e}}}{A_{\mathrm{B}}},
$$

where $A_{\mathrm{e}}$ is equivalent shear area assuming that the stiffness properties of each wall are uniform over its height:

$$
A_{\mathrm{e}}=\sum_{i=1}^{N W}\left(\frac{H}{H_{i}}\right)^{2} \frac{A_{i}}{\left[1+0,83\left(\frac{H_{i}}{D_{i}}\right)^{2}\right]},
$$

where $A_{i}, H_{i}$ and $D_{i}$ are the area, height, and dimension in the direction under consideration of the $i^{\text {th }} \mathrm{SW}$ and NW is the number of shear walls.
Goel and Chopra [2] determined $\bar{C}$ from regression analysis to account for variations in properties among various buildings and for differences between building behaviour and its idealization. Based on Eq. (6), a regression analysis was carried out on 17 measured period values from $9 \mathrm{RC} \mathrm{SW}$ buildings subjected to seismic excitations. The values of $\bar{C}$ determined from all available data should be modified to recognize that the period of a concrete building lengthens at moderate-tohigh levels of ground shaking (Goel and Chopra 1998 [2]). Regression analysis of the data from buildings experiencing peak ground acceleration $a_{\mathrm{g}} \geq 0,15 \mathrm{~g}$ gives:

$$
\begin{gathered}
T_{\mathrm{L}}=0,0019 \frac{1}{\sqrt{\overline{A_{\mathrm{e}}}}} H, \\
T_{\mathrm{U}}=0,0026 \frac{1}{\sqrt{\overline{A_{\mathrm{e}}}}} H .
\end{gathered}
$$

Goel and Chopra (1998) [2] also point out the poor correlation between $H / \sqrt{D}$ and the measured period, where $D$ is the plan dimension parallel to the direction along which the period is evaluated.

\section{Structure models with RC shear walls}

Since it was desired to investigate the relationship between the number of storeys and the fundamental period of vibration, the structures were modelled with different layout dispositions and number of storeys.

\subsection{Geometrical characteristics}

Structures were composed of a base 3D unit whose dimensions were obtained by observation of real structures in our surroundings. In that way the results were more proximate to the periods of vibration of the real structures. The base unit had a span of $5 \mathrm{~m}$ in the direction of both longitudinal axis and with height of $3 \mathrm{~m}$. $\mathrm{RC}$ walls were modelled with a thickness of $30 \mathrm{~cm}$ what is in accordance with EN1998-1 [26] requirement for minimum bearing wall thickness of $20 \mathrm{~cm}$. The largest model was set to be nine base units in length, ten base units in height and three base units in width. Required area of built-in walls was determined as a $1,5 \%$ of total layout area of the building. In order to fulfil EN1998-1 [26] requirement for structural uniformity in plan and in elevation, structures were modelled with an odd number of base units thus avoiding eccentricity between mass and stiffness. Once walls were positioned in building layout, it was determined that the required wall quantity for achieving structural uniformity for models with even number of base units considerably exceeds required 1,5\% of total layout area. This made buildings with even number of base models too stiff for further analysis. Fig. 1 shows three dispositions of bearing walls in the observed structures. 

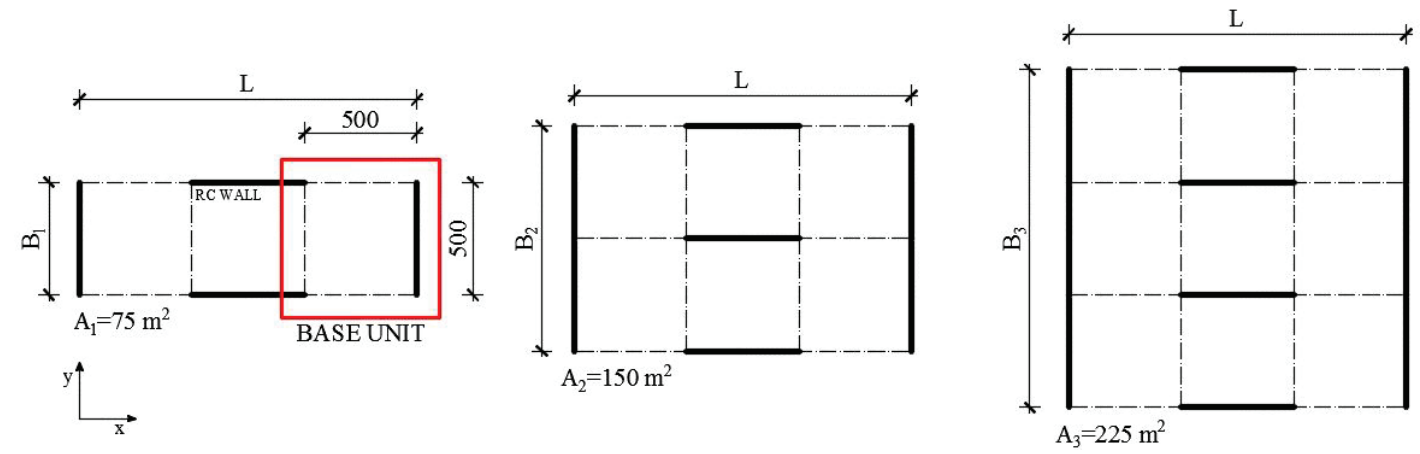

Figure 1 Layout of bearing walls in models $(\mathrm{cm})$

Table 1 Quantities of required and built-in walls

\begin{tabular}{|c|c|c|c|c|c|c|c|c|c|c|c|c|c|c|c|c|c|}
\hline$L$ & $B_{1}$ & $B_{2}$ & $B_{3}$ & $A_{1}$ & $A_{2}$ & $A_{3}$ & $1,5 \% A_{1}$ & $1,5 \% A_{2}$ & $1,5 \% A_{3}$ & $A_{\mathrm{u}} 1-x$ & $A_{\mathrm{u}} 1-y$ & $A_{\mathrm{u}} 2-x$ & $A_{\mathrm{u}} 2-y$ & $A_{\mathrm{u}} 3-x$ & $A_{\mathrm{u}} 3-y$ \\
\hline \multicolumn{3}{|c|}{$\mathrm{m}$} & \multicolumn{9}{|c|}{$\mathrm{m}^{2}$} & \multicolumn{6}{|c|}{$\mathrm{m}^{2}$} \\
\hline 15 & 5 & 10 & 15 & 75 & 150 & 225 & 1,1 & 2,3 & 3,4 & 3 & 3 & 4,5 & 6 & 6 & 9 \\
\hline 25 & 5 & 10 & 15 & 125 & 250 & 375 & 1,9 & 3,8 & 5,6 & 6 & 6 & 9 & 12 & 12 & 18 \\
\hline 35 & 5 & 10 & 15 & 175 & 350 & 525 & 2,6 & 5,3 & 7,9 & 9 & 6 & 13,5 & 12 & 18 & 18 \\
\hline 45 & 5 & 10 & 15 & 225 & 450 & 675 & 3,4 & 6,8 & 10,1 & 12 & 9 & 18 & 18 & 24 & 27 \\
\hline
\end{tabular}

Table 2 Percentages of built-in walls

\begin{tabular}{|c|c|c|c|c|c|c|}
\hline Models & $\%_{\mathrm{u}} 1-x$ & $\%_{\mathrm{u}} 1-y$ & $\%_{\mathrm{u}} 2-x$ & $\%_{\mathrm{u}} 2-y$ & $\%_{\mathrm{u}} 3-x$ & $\%_{\mathrm{u}} 3-y$ \\
\hline \multirow{4}{*}{ Series 1 } & 4,00 & 4,00 & 3,00 & 4,00 & 2,67 & 4,00 \\
\cline { 2 - 7 } & 4,80 & 4,80 & 3,60 & 4,80 & 3,20 & 4,80 \\
\cline { 2 - 7 } & 5,14 & 3,43 & 3,86 & 3,43 & 3,43 & 3,43 \\
\cline { 2 - 7 } & 5,33 & 4,00 & 4,00 & 4,00 & 3,56 & 4,00 \\
\hline \multirow{4}{*}{ Series 2 } & 4,00 & 4,00 & 4,00 & 4,00 & 2,67 & 2,67 \\
\cline { 2 - 7 } & 2,40 & 2,40 & 2,40 & 2,40 & 1,60 & 1,60 \\
\cline { 2 - 7 } & 1,71 & 1,71 & 1,71 & 1,71 & 1,71 & 1,71 \\
\cline { 2 - 7 } & 2,67 & 2,67 & 2,00 & 2,67 & 1,78 & 1,78 \\
\hline
\end{tabular}

In Tab. 1 required and built-in wall quantities for different structure layout are listed. Tab. 2 gives percentages of built-in walls in structure layout from which can be seen that the percentages vary from $1,6 \%$ to $5,4 \%$. Series 1 represents starting models in which walls were placed in such a way to fulfil requirements for structural uniformity in building layout and Series 2 represents same models after further optimization of wall placement. From Tab. 2 it can be seen that the optimased placement gives quantites closer to required $1,5 \%$ of total building layout.

\subsection{Numerical models}

Numerical modal analysis was performed using SAP2000 [28, 29] software in order to determine the vibration modes of observed structures. These modes are useful to understand the behaviour of the structure and are the basis for modal superposition in response-spectrum load cases. There are two types of modal analysis in the applied software: eigenvector and Ritz-vector analysis. Eigenvector analysis determines the undamped freevibration mode shapes and frequencies of the system. These natural modes provide an excellent insight into the behaviour of the structure. Ritz-vector analysis seeks to find modes that are excited by a particular loading. Ritz vectors can provide a better basis than eigenvectors when used for response-spectrum or time-history analyses that are based on modal superposition [29].

Eigenvector analysis involves the solution of the generalized eigenvalue problem:

$$
\left[\boldsymbol{K}-\boldsymbol{\Omega}^{2} \cdot \boldsymbol{M}\right] \cdot \boldsymbol{\Phi}=0
$$

where $\boldsymbol{K}$ is the stiffness matrix, $\boldsymbol{M}$ is the diagonal mass matrix, $\boldsymbol{\Omega}^{2}$ is the diagonal matrix of eigenvalues, and $\boldsymbol{\Phi}$ is the matrix of corresponding eigenvectors (i.e. mode shapes).

Eq. (12) can be written as:

$[\boldsymbol{K}-\lambda \cdot \boldsymbol{M}] \cdot \boldsymbol{\Phi}=0$,

where $\lambda=\boldsymbol{\Omega}^{2}$. The number of solutions for Eq. (13) for $\lambda \neq 0$ is equal to the rank of the mass matrix. Each of the eigenvalue has its unique eigenvector $\boldsymbol{\Phi} \neq 0$ whose ordinates are relative because of the homogenous nature of the system [30].

Nontrivial solution exists if the system determinant is equal to zero:

$[\boldsymbol{K}-\lambda \cdot \boldsymbol{M}]=0$,

what leads to characteristic third order equations. By solving those equations one obtains eigenvalues, $\lambda$. The square root of the eigenvalue gives the angular frequency of the system and subsequently the frequency and period can be obtained [30]:

$$
\begin{aligned}
& f=\frac{\omega}{2 \pi}, \\
& T=\frac{1}{f} .
\end{aligned}
$$


Modal analysis is always linear and can be based on the stiffness of the unstressed structure (before applying any load) or after the nonlinear analysis. In the first case stiffness remains unchanged but after the nonlinear analysis stiffness is reduced by cracking (in concrete elements) or plastic hinge formation (in steel elements). Stiffness was taken as unchanged in this analysis what is in accordance with the recommendation given in EN 1998-1 [26] which states that the calculation can be performed with the assumption of uncracked bearing walls. Bearing walls were modelled as shell elements. The shell element is a three- or four- node formulation that combines membrane and plate-bending behaviour. A four-point numerical integration formulation is used for the shell stiffness. Stresses, internal forces and moments, in the element local coordinate system, are evaluated at the 2-by-2 Gauss integration points and extrapolated to the joints of the element (Fig. 2) [29].

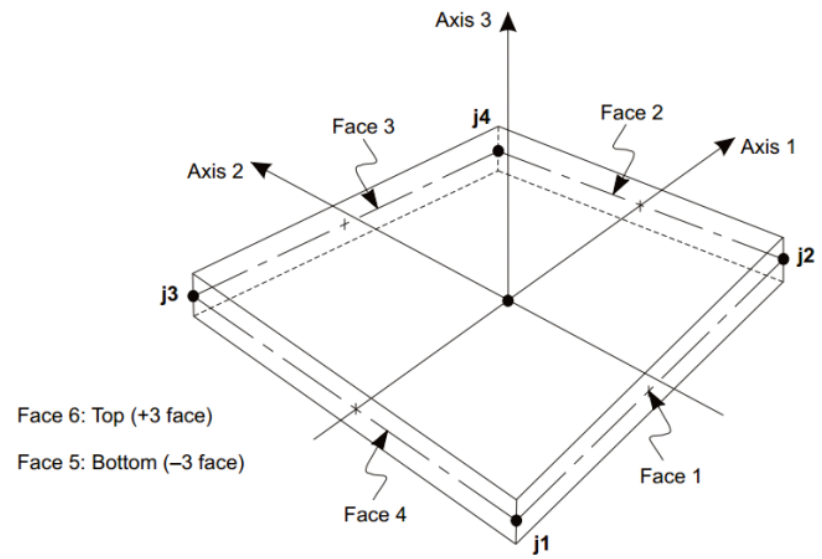

Figure 2 Four-node Quadrilateral Shell Element [29]

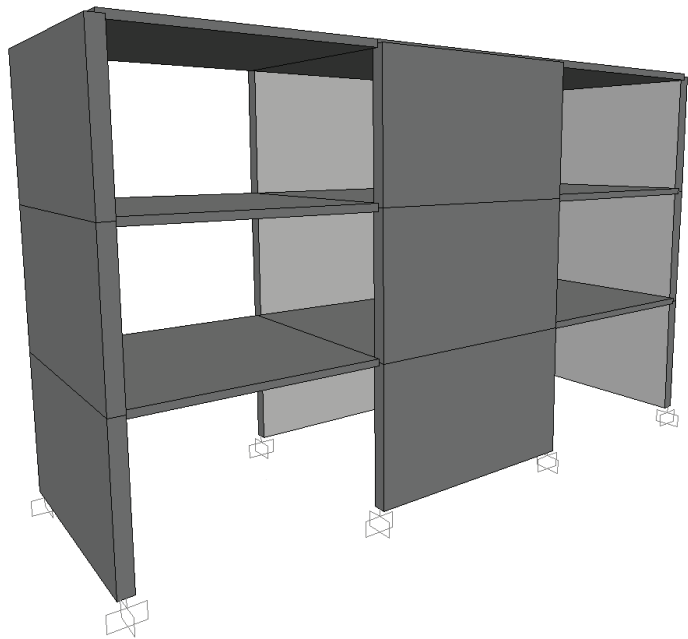

Figure 3 Structure model in SAP2000 $\left(n_{x} / n_{y} / n_{z}=1 / 3 / 3\right)$

Edge constraints are assigned to elements in order to automatically connect all joints that are on the edge of the element to the adjacent corner joints of the element. In that way wall continuity throughout the structure height was achieved (Fig. 3). Concrete slabs were modelled as rigid diaphragms connecting vertical elements, in our case shear walls, and transfer all horizontal earthquake loading into vertical elements. Materials used for building modelling were concrete $\mathrm{C} 25 / 30$ with modulus of elasticity $E_{\mathrm{c}}=30500 \mathrm{~N} / \mathrm{mm}^{2}$ and steel reinforcement B500B with modulus of elasticity $E_{\mathrm{s}}=210000 \mathrm{~N} / \mathrm{mm}^{2}$.

\section{Comparison of periods of RC SW model structures with period obtained using building codes}

Numerically obtained periods were compared with values obtained by expressions in codes, what can be seen in Figs. 4, 5 and 6, with the following description of symbols:

$n_{x}$ - number of base units in $\mathrm{x}$ direction,

$n_{y}$ - number of base units in y direction,

$n_{z}-$ number of base units in $\mathrm{z}$ direction,

$A_{x}$ - area of shear walls in $\mathrm{x}$ direction,

$A_{y}$ - area of shear walls in y direction,

$A_{\text {layout }}-$ area of structure layout.

The figures show a comparison for three different models, a model with one base unit in $x$ direction and three base units in $y$ direction, a model with two base units in $x$ direction and three base units in $y$ direction and model with three base units in $x$ direction and three base units in $y$ direction.

The comparison showed that model periods can be best approximated by expression given by Goel and Chopra [2] (Eq. (10) and (11)) for models with one and two bays. For models with three bays, expression from Goel and Chopra shows high difference. Model period values are somewhat smaller in comparison with values obtained by expressions given in ATC3-06 [12] for models with one bay in $\mathrm{x}$ direction, but for models with two and three bays there are huge differences. The highest difference is noticed for all models in comparison to the expression given in EN1998-1 [26].

The influence of various percentages of shear walls per floor unit and different number of bays, e.g. different plans were investigated by comparing periods for different structure models. This led to certain conclusions. First, the fundamental periods for models with same wall area but different ratio of bays was analyzed. Periods of models with $4 \%$ of wall arranged in different layouts, e.g. with $n_{x} / n_{y}=1 / 3$ and $2 / 3$ are presented in Fig. 7a). It is obvious that there are differences in the obtained periods for those structures. This comparison can also be seen in Tab. 3. Except for the first two storeys, the differences are between $25 \%$ and $31 \%$. Similar results are shown for structures with $n_{x} / n_{y}=1 / 9$ and $3 / 3$ - an average difference of $20 \%$ in periods are obtained. This leads to the conclusion that the plan area, e.g. number of bays is important for the calculation of fundamental period.

A second analysis was performed in which the comparison was done for the same ratio $n_{x} / n_{y}$ but different percentage of built-in walls. Differences between obtained periods can be seen in Fig. 8 a) and b) for both layouts $\left(n_{x} / n_{y}=2 / 7\right.$ and $\left.3 / 5\right)$. Tab. 4 gives the percentage difference for models and it is shown that the range is also from $20 \%$ to $30 \%$.

These comparisons lead to the conclusion that both, the percentage of walls and number of bays are important for determining the fundamental periods. 

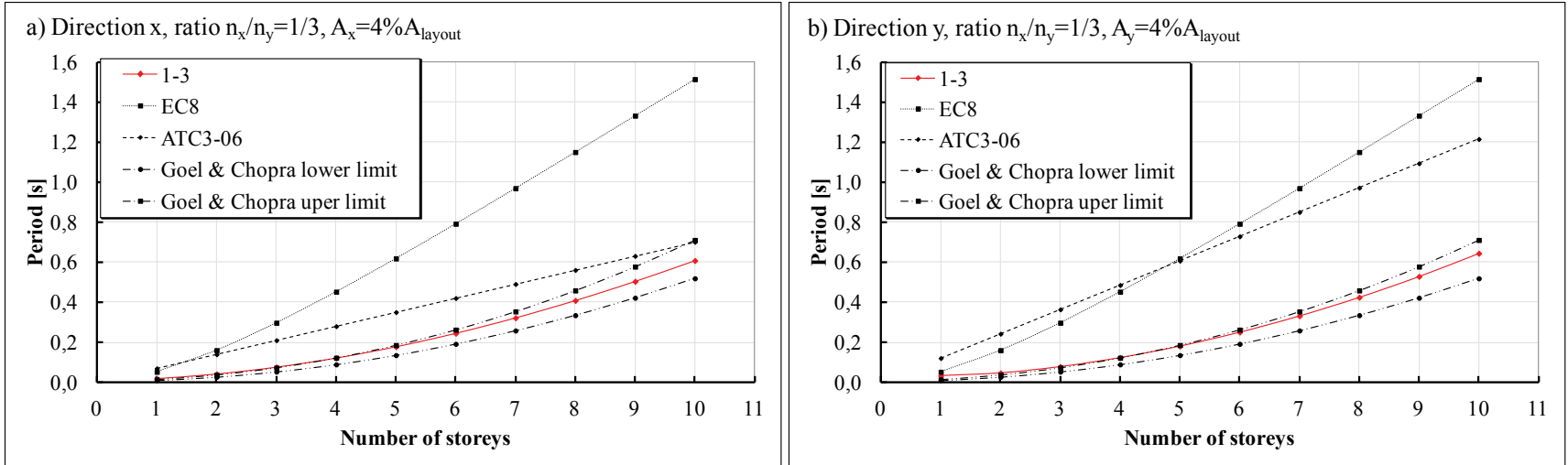

Figure 4 Period comparison for structure model with ratio $n_{x} / n_{y}=1 / 3$ for: a) $x$ direction and b) $y$ direction.
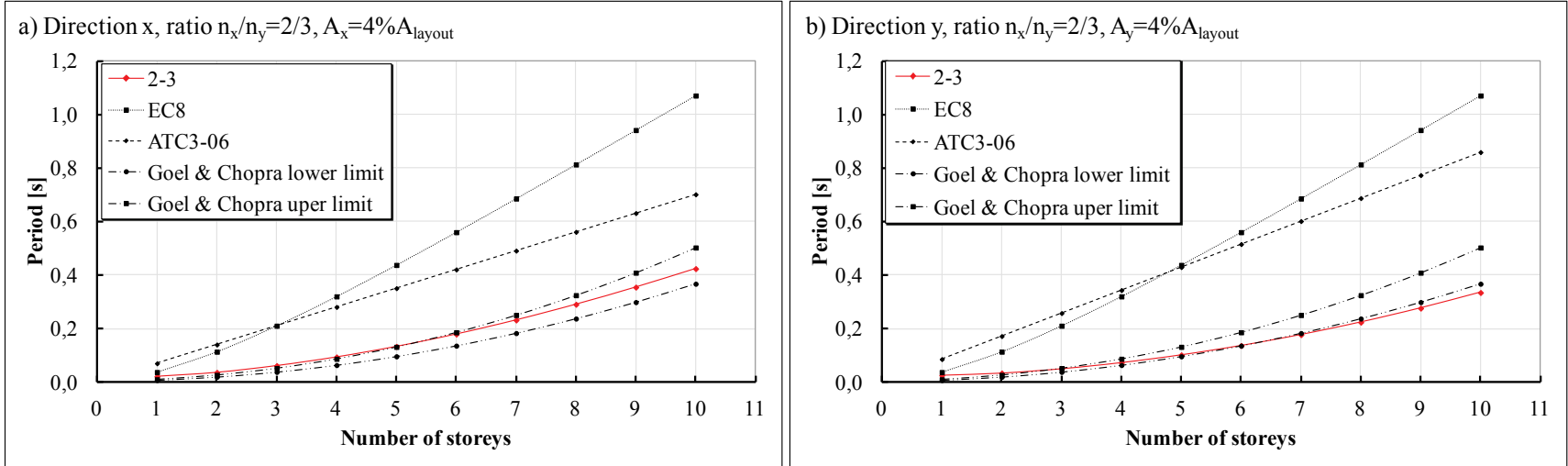

Figure 5 Period comparison for structure (model) with ratio $n_{x} / n_{y}=2 / 3$ : a) $x$ direction and b) $y$ direction.
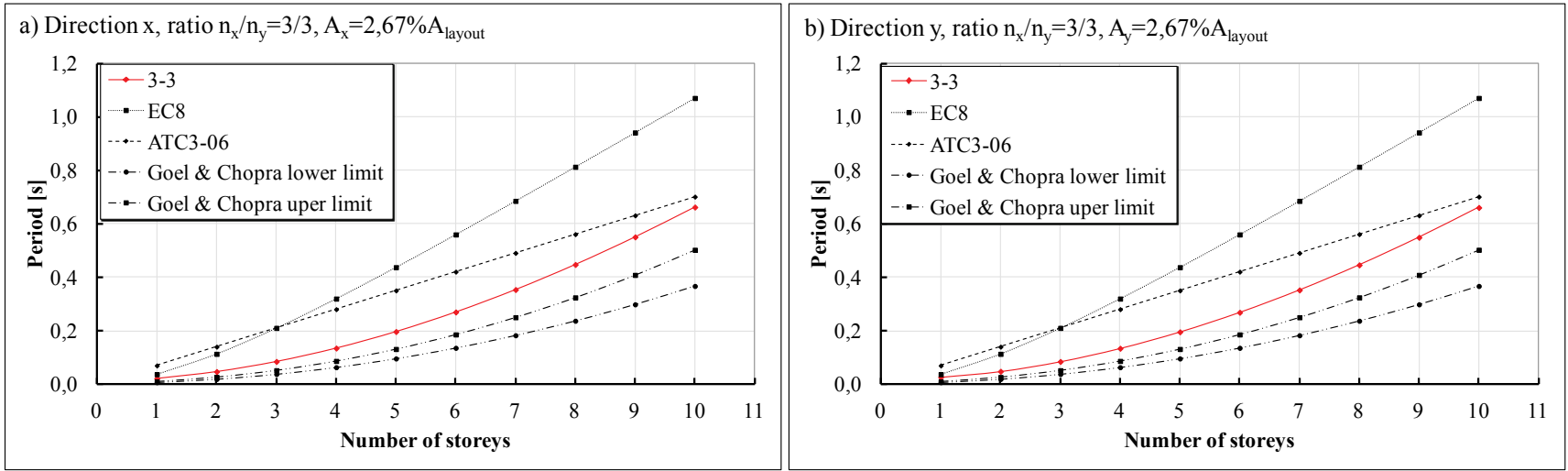

Figure 6 Period comparison for structure (model) with ratio $n_{x} / n_{y}=3 / 3$ : a) $x$ direction and b) $y$ direction
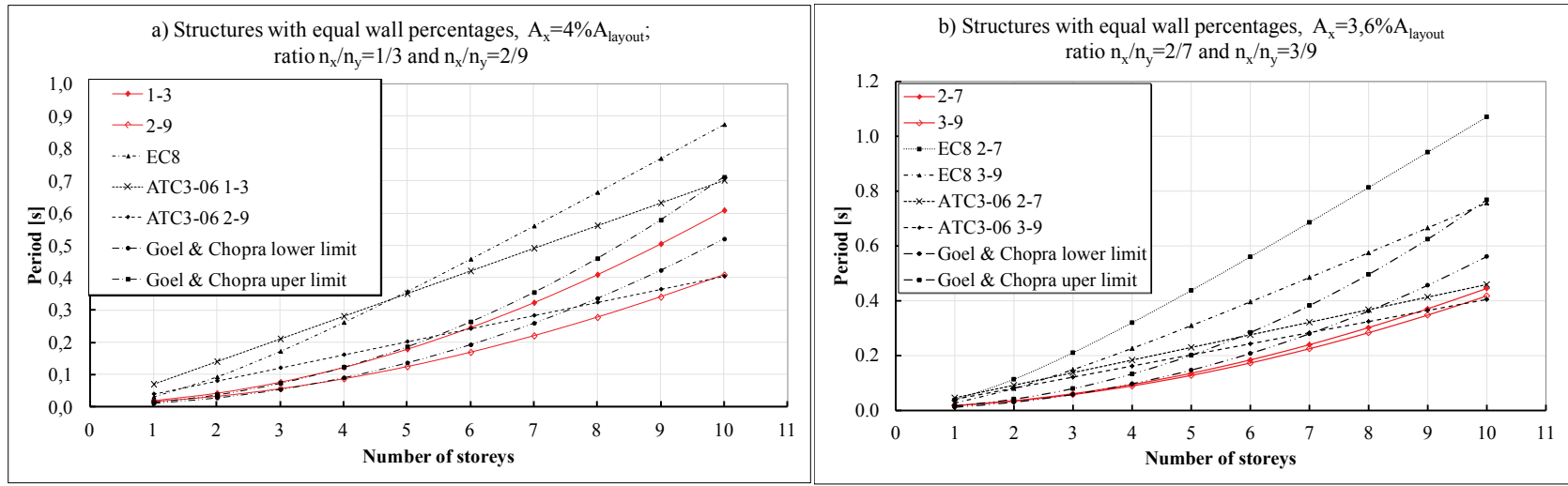

Figure 7 Period comparison for structures with same wall area but different ratio $n_{x} / n_{y}$ for: a) $4 \%$ of walls and b) $2,67 \%$ of walls 
Table 3 Period comparison for structure models with same wall area but different ratio $n_{x} / n_{y}$

\begin{tabular}{|c|c|c|c|c|c|c|}
\hline \multirow{2}{*}{$\begin{array}{c}\text { Number of } \\
\text { storeys }\end{array}$} & \multicolumn{3}{|c|}{$A_{x}=4 \% A_{\text {layout }}$} & \multicolumn{3}{c|}{$A_{x}=2,67 \% A_{\text {lavout }}$} \\
\cline { 2 - 6 } & $1-3$ & $2-9$ & Difference (\%) & $1-9$ & $3-3$ & Difference (\%) \\
\hline 1 & 0,019 & 0,02143 & 11,1 & 0,021 & 0,022 & 2,8 \\
\hline 2 & 0,042 & 0,03628 & 14,4 & 0,039 & 0,047 & 18,0 \\
\hline 3 & 0,077 & 0,06154 & 19,7 & 0,066 & 0,085 & 22,2 \\
\hline 4 & 0,122 & 0,09385 & 23,1 & 0,102 & 0,135 & 24,5 \\
\hline 5 & 0,179 & 0,13324 & 25,4 & 0,149 & 0,197 & 24,3 \\
\hline 6 & 0,246 & 0,17943 & 26,9 & 0,219 & 0,270 & 19,1 \\
\hline 7 & 0,323 & 0,23205 & 28,1 & 0,273 & 0,354 & 22,9 \\
\hline 8 & 0,409 & 0,29064 & 29,0 & 0,345 & 0,448 & 23,0 \\
\hline 9 & 0,505 & 0,35473 & 29,7 & 0,426 & 0,551 & 22,6 \\
\hline 10 & 0,608 & 0,42385 & 30,3 & 0,517 & 0,663 & 22,0 \\
\hline
\end{tabular}
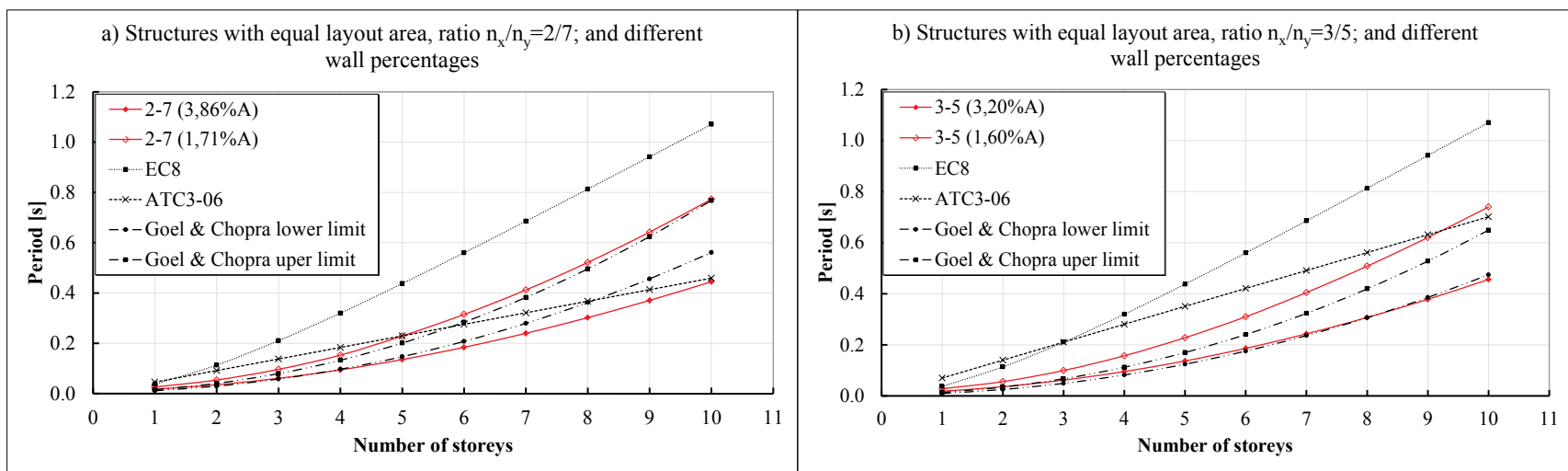

Figure 8 Period comparison for structures with same layout area but different wall percentages

Table 4 Period comparison for structure models with same ratio $n_{x} / n_{y}$ but different wall area

\begin{tabular}{|c|c|c|c|c|c|c|}
\hline \multirow{2}{*}{$\begin{array}{c}\text { Number of } \\
\text { storeys }\end{array}$} & \multicolumn{3}{|c|}{$n_{x} / n_{y}=2 / 7$} & \multicolumn{3}{c|}{$n_{x} / n_{y}=3 / 5$} \\
\cline { 2 - 7 } & $3,86 \% A_{\text {layout }}$ & $1,71 \% A_{\text {layout }}$ & Difference $(\%)$ & $3,20 \% A_{\text {layout }}$ & $1,60 \% A_{\text {layout }}$ & Difference $(\%)$ \\
\hline 1 & 0,019 & 0,017 & 13,3 & 0,021 & 0,022 & 2,8 \\
\hline 2 & 0,042 & 0,033 & 22,2 & 0,039 & 0,047 & 18,0 \\
\hline 3 & 0,077 & 0,056 & 26,3 & 0,066 & 0,085 & 22,2 \\
\hline 4 & 0,122 & 0,087 & 28,7 & 0,102 & 0,135 & 24,5 \\
\hline 5 & 0,179 & 0,125 & 30,2 & 0,149 & 0,197 & 24,3 \\
\hline 6 & 0,246 & 0,169 & 31,2 & 0,219 & 0,270 & 19,1 \\
\hline 7 & 0,323 & 0,220 & 31,8 & 0,273 & 0,354 & 2,9 \\
\hline 8 & 0,409 & 0,277 & 32,3 & 0,345 & 0,448 & 23,0 \\
\hline 9 & 0,505 & 0,340 & 32,6 & 0,426 & 0,551 & 2,6 \\
\hline
\end{tabular}

\section{Conclusions}

The actual forces that will occur over the lifetime of the structure cannot be known. Seismic forces on the structure result from the vibration of the structure mass. The fundamental period appears in the equations given in the standards for the calculation of yield base shear and lateral forces. Therefore, in phases of planning and design of building, it is important to carefully consider the fundamental period of the building.

The aim of the paper was to present a review of previous research, evaluation of current code formulas and investigation of the influence of parameters that affect the period of RC SW dominant buildings.

Since previous analytical research was mainly conducted on RC MRF buildings, in this study investigation of analytically obtained periods on RC SW dominant structures was performed.

Several expressions for the evaluation of fundamental period given by building codes were analysed. Using a database of $480 \mathrm{RC} \mathrm{SW}$ models, the differences between the periods of the models and the corresponding periods obtained using building codes indicate that expressions can be improved. This is particularly important since the characteristics of the structures that have yet to be designed cannot be known and this is a starting assumption for the design of earthquake resistant structures.

Periods obtained by numerical analysis are smaller in comparison to ATC3-06 and EN 1998-1:2004. Difference to ATC3-06 ranges from 2,7\% to $85 \%$ if both directions are considered; if only $\mathrm{x}$ direction is observed then can be noticed that as the height of the building increases period difference is decreasing (from around $80 \%$ to $3 \%$ ). This is not the case for $y$ direction where differences oscillate around some value dependent on number of base models considered (for 1-3 model difference is about $66 \%$, for 29 model about $80 \%$, for 3-3 model about $74 \%$ ), same trend is observed if results for both directions are compared to EN 1998-1:2004.

Also, the influence of the percentage of $\mathrm{RC}$ walls and the number of bays, e.g. plan disposition were investigated. The differences between obtained periods for different models with equal percentage of walls and 
different layouts with the same percentage of walls led to conclusion that the number of bays should also be taken into account in expressions for the fundamental period of RC SW structures.

\section{References}

[1] Hong, L.; Hwang, W. Empirical formula for fundamental vibration periods of reinforced concrete buildings in Taiwan. // Earthquake Engineering and Structural Dynamics. 29(2000), pp. 327-333. DOI: 10.1002/(SICI)10969845(200003)29:3<327::AID-EQE907>3.0.CO;2-0

[2] Goel, R. K.; Chopra, A. K. Period formulas for concrete shear wall buildings. // Journal of Structtural Engineering. 124, 4(1998), pp. 426-433. DOI: 10.1061/(ASCE)07339445(1998)124:4(426)

[3] Kwon, O. S.; Kim, E. S. Evaluation of building period formulas for seismic design. // Earthquake Engineering and Structural Dynamics. 39, 14(2010), pp. 1569-1583. DOI: 10.1002/eqe.998

[4] Masi, A.; Vona, M. Experimental and numerical evaluation of the fundamental period of undamaged and damaged RC framed buildings. // Bulletin of Earthquake Engineering. 8, 3(2010), pp. 643-656. DOI: 10.1007/s10518-009-9136-3

[5] Draganić, H.; Hadzima-Nyarko, M.; Morić, D. Comparison of RC Frames Periods with the Empiric Expressions given in Eurocode 8. // Tehnički vjesnik-Technical Gazette. 17, 1(2010), pp. 93-100.

[6] Mehanny, S. S. F. Are theoretically calculated periods of vibration for skeletal structures error-free? // Earthquakes and Structures. 3, 1(2012), pp. 17-35. DOl: 10.12989/eas.2012.3.1.017

[7] Lee, L.-H.; Chang, K.-K.; Chun, Y.-S. Experimental Formula for the Fundamental Period of RC Buildings with Shear-Wall Dominant System. // The Structural Design of Tall Build. 9(2000), pp. 295-307. DOI: 10.1002/10991794(200009)9:4<295::AID-TAL153>3.0.CO;2-9

[8] Oliveira C. S.; Navarro M. Fundamental periods of vibration of RC buildings in Portugal from in-situ experimental and numerical techniques. // Bulletin of Earthquake Engineering. 8, 3(2010), pp. 609-642. DOI: 10.1007/s10518-009-9162-1

[9] Housner, G. W.; Brady, G. Natural periods of vibration of buildings. // Journal of Engineering Mechanics Division, Proceedings of the American Society of Civil Engineers. 89, 4(1963), pp. 31-65.

[10] Cole, E. E.; Tokas, C. V.; Meehan, J. F.; Analysis of recorded building data to verify or improve 1991 Uniform Building Code (UBC) period of vibration formulas, Proceedings of SMIP92, Strong Motion Instrumentation Program, Divisions of Mines and Geology, Califorania Department of Conservation, Sacramento, May 1992, pp. 6$1 \div 6-12$.

[11] Li, Y.; Mau, S. T. Learning from recorded earthquake motion of buildings. // Journal of Structural Engineering. 123, 1(1997), pp. 62-69. DOI: 10.1061/(ASCE)07339445(1997)123:1(62)

[12] ATC-78 Tentative provisions for the development of seismic regulations for buildings. Report No. ATC3-06, Applied Technology Council, Palo Alto, California, 1978.

[13] Jalali, A.; Salem, A. Fundamental Periods of Buildings Measured from Ambien Vibration Measurements. // The 2005 World Sustainable Building Conference, Tokyo, 2729 September 2005. pp. 2577-2584.

[14] Gallipoli, M.R.; Mucciarelli, M.; Šket-Motnikar, B.; P. Zupančić, P.; Gosar, A.; Prevolnik, S.; Herak, M.; Stipčević, J.; Herak, D.; Milutinović, Z.; Olumčeva, T. Empirical estimates of dynamic parameters on a large set of
European buildings. // Bulletin of Earthquake Engineering. 8(2010), pp. 593-607. DOI: 10.1007/s10518-009-9133-6

[15] Hart, G. C.; Thurston, S. J.; Englekirk, R. E. Seismic evaluation of a tall reinforced concreteframe building. // Proceedings of the ASCE Structures Conference '89, San Francisco, California, May 1989, pp. 277-286.

[16] Ventura, C. E.; Schuster, N. D. Structural dynamic properties of a reinforced concrete high-rise building during construction. // Canadian Journal of Civil Engineering. 23(1996), pp. 950-972. DOI: 10.1139/196-901

[17] Naeim, F. Performance of extensively instrumented building during the January 17, 1994 Northridge earthquake - An interactive information system, Report No. 977530.68 John A. Martina and Associates, INC., Research and Development Department, February 1997.

[18] Anderson, J. C.; Bertero, V. V. Seismic performance of a six story reinforced concrete building, Report No. UBC/EERC 93-01, University of California at Berkeley, July 1997.

[19] De la Llera, J. C.; Chopra, A. K. Evaluation of seismic code provisions using strong-motion buildings records from the 1994 Northridge earthquake, Report No. UBC/EERC97/16, University of California at Berkeley, May 1998.

[20] Balkaya, C.; Kalkan, E. Estimation of fundamental periods of shear-wall dominant building structures. // Earthquake Engineering and Structural Dynamics. 32(2003), pp. 985998. DOI: 10.1002/eqe.258

[21] Uniform Building Code. International Conference of Building Oficials, Whittier, CA, 1997

[22] Ministry of Public Works and Settlement. Specification for Structures to be Built in Disaster Areas, Ankara, Turkey, 1998.

[23] Verderame, G.M.; Iervolino, I.; Manfredi, G. Elastic period of sub-standard reinforced concrete moment resisting frame buildings. // Bulletin of Earthquake Engineering. 8(2010), pp. 955-972. DOI: 10.1007/s10518-010-9176-8

[24] Hadzima-Nyarko, M.; Nyarko, E. K.; Morić, D.; Draganić, H. New Direction Based (Fundamental) Periods of RC Frames Using Genetic Algorithms. // Proceedings of 15 World Conference of Earthquake Engineerong (15WCEE). Lisboa, 2012.

[25] Ricci, P.; Verderame, G. M.; Manfredi, G. Analytical investigation of elastic period of infilled RC MRF buildings. // Engineering Structures. 33(2011), pp. 308-319. DOI: 10.1016/j.engstruct.2010.10.009

[26] EN 1998-1:2004, Eurocode 8: design of structures for earthquake resistance - part 1: general rules, seismic actions and rules for buildings. European Committee for Standardization, 2004.

[27] Goel, R. K.; Chopra, A. K. Period Formulas for Moment Resisting Frame Buildings. // Journal of Structural Engineering, ASCE. 123, 11(1997), pp. 1454-1461. DOl: 10.1061/(ASCE)0733-9445(1997)123:11(1454)

[28] Wilson, E.; Habibullah, A. SAP2000, Structural Analysis Program. Computers and Structures, Inc., University Avenue, Berkeley, California, USA, 1995.

[29] Berkeley, C. CSI Analysis Reference Manual for SAP2000. Computers and Structures, Inc., Berkeley, California, 2007.

[30] Čaušević, M. Dinamika konstrukcija: diskretni sustavi. Školska knjiga, 2005. 


\section{Authors' addresses}

Doc. dr. sc. Marijana Hadzima-Nyarko, dipl. ing. grad. J. J. Strossmayer University of Osijek Faculty of Civil Engineering Osijek Drinska 16a, 31000 Osijek, Croatia

Tel: +385 31274 37, E-mail: mhadzima@gfos.hr

Prof. dr. sc. Dragan Morić, dipl. ing. grad.

J. J. Strossmayer University of Osijek

Faculty of Civil Engineering Osijek

Drinska 16a, 31000 Osijek, Croatia

Tel: +385 31274 377, E-mail: dmoric@gfos.hr

Dr. sc. HrvojeDraganić, dipl. ing. grad.

J. J. Strossmayer University of Osijek

Faculty of Civil Engineering Osijek

Drinska 16a, 31000 Osijek, Croatia

Tel: +385 31274 377, E-mail: draganic@gfos.hr

Mr. sc. TihomirŠtefić, mag. ing. aedif.

J. J. Strossmayer University of Osijek

Faculty of Civil Engineering Osijek

Drinska 16a, 31000 Osijek, Croatia

Tel: +385 31274 377, E-mail: tstefic@gfos.hr 